\title{
The Effects of Propagation Techniques on Cell Wall Chemistry and Wood Anatomy in Micropropagated and Grafted Plants of the Dutch Elm Hybrid 'Dodoens'
}

\author{
Jaroslav Ďurkovič ${ }^{1}$ \\ Department of Phytology, Technical University, 96053 Zvolen, Slovakia \\ František Kačík \\ Department of Chemistry and Chemical Technologies, Technical University, 96053 Zvolen, Slovakia \\ Miroslava Mamoňová \\ Department of Wood Science, Technical University, 96053 Zvolen, Slovakia \\ Monika Kardošová \\ Department of Phytology, Technical University, 96053 Zvolen, Slovakia
}

Roman Longauer
Department of Silviculture, Mendel University, 61300 Brno, Czech Republic; and Forest Research
Institute, National Forest Centre, 96092 Zvolen, Slovakia
Jana Krajňáková
Department of Agricultural and Environmental Science, University of Udine, 33100 Udine, Italy; and
the Department of Biology, University of Oulu, 90014 Oulu, Finland

AdDitional INDEX wORDs. D-glucose, degree of polymerization of cellulose, dutch elm disease, fiber morphology, syringylto-guaiacyl ratio in lignin, vascular anatomy

\begin{abstract}
Determination of wood anatomy traits and the chemical attributes of plant cell walls is of great importance for the evaluation of both the effects of hybridization and the results of breeding strategies within the genus Ulmus, because these are both aimed at an enhanced tolerance to dutch elm disease (caused by Ophiostoma ulmi and O. novo-ulmi) and to the improvement of trees having desired mechanical properties. The objective of this study was to determine whether the routinely applied vegetative propagation techniques of in vitro micropropagation or grafting would result in any change to lignin monomer composition and content, macromolecular traits of cellulose, neutral sugar composition, or the vascular and fiber anatomy traits in the stems of the dutch elm hybrid cultivar Dodoens (i.e., openpollinated Ulmus glabra 'Exoniensis' $\times$ U. wallichiana P39). Propagation techniques appeared to have no direct effect on lignin monomer composition. The differences in the relative proportion of guaiacyl units in lignin between the stock types were not significant, showing that no advantage could be attributed to either stock type toward an enhanced tolerance to dutch elm disease. The micropropagated plants reached significantly higher values for 13 traits $(32.5 \%)$, primarily associated with the relative proportion of D-glucose and the macromolecular traits of cellulose to compensate for a lower content of holocellulose. The grafts reached higher values for 10 traits $(25 \%)$, including the relative proportions of $D$-xylose, D-mannose, and D-galactose. The effect of the rootstock might contribute to different amounts of these cell wall substances in the grafts. The grafts also reached a higher lignin content, which may provide minor advantages in terms of mechanical and physical properties to the cell walls of this stock type. Similarities between the stock types were found for 17 traits $(\mathbf{4 2 . 5 \% )}$. Both stock types formed compact homogeneous clusters clearly separated from each other in the multivariate wood trait analysis.
\end{abstract}

Since 1918, when dutch elm disease (DED) emerged in Holland, a majority of both wild and street populations of Ulmus trees in Europe and North America have been destroyed. The ascomycetous fungi Ophiostoma ulmi and $O$. novo-ulmi were identified as the causative organisms of DED. The former

Received for publication 12 Aug. 2014. Accepted for publication 8 Oct. 2014. This work was supported by funding from the Slovak scientific grant agency VEGA $(1 / 0132 / 12)$.

We thank Dr. I. Čaňová, Dr. M. Moravčík, Dr. B. Seman, and Mr. M. Mamoň for their technical assistance and Mrs. E. Ritch-Krč for language revision.

${ }^{1}$ Corresponding author. E-mail: jaroslav.durkovic@tuzvo.sk. fungus was responsible for the first pandemic of the disease in the $1920 \mathrm{~s}-40 \mathrm{~s}$, whereas the latter highly pathogenic and aggressive fungus was responsible for the advent of the second pandemic during the 1970s (Brasier, 1991; Smalley and Guries, 1993). A rapid emergence of hybrids between two subspecies of O. novo-ulmi has recently been reported, and it is likely that complex hybrid swarms are now expanding across the European continent (Brasier and Kirk, 2010). The initial elm breeding programs, launched in The Netherlands, were focused on the identification of resistant elms and emphasized the native European elms, especially U. glabra and U. minor. Asian elms, particularly $U$. wallichiana and $U$. pumila, proved to be a useful 
additional source of DED-resistance genes (Heybroek, 1983; Santini et al., 2008, 2010; Smalley and Guries, 1993). A series of new dutch elm hybrid cultivars were released in the 1960s and 1970s, and several hundred thousands grafted trees planted widely in Europe (Gerhold, 1970; Hiemstra et al., 2006) now show a varying degree of resistance to $O$. novo-ulmi isolates.

The use of tissue culture techniques assists in the propagation of high-quality plant material identified by tree breeding programs. In addition to elm breeding strategies, in vitro propagation methods may significantly contribute to the efforts of tree improvement through existing germplasm conservation, in vitro selection, and rapid distribution of new and improved cultivars (Biroščíková et al., 2004; Conde et al., 2008; Durkovič et al., 2010; Harvengt et al., 2004; Shukla et al., 2012). Transgenic elms showing reduced DED symptoms have been regenerated (Gartland et al., 2005; Newhouse et al., 2007), and small-scale field tests of transgenic elms have been established (Merkle et al., 2007).

Determination of the chemical attributes of plant cell walls is of great importance for evaluating both the effects of hybridization and the results of plant breeding. The major chemical components of woody plant cell walls are the polysaccharide fractions (holocellulose) and lignin. Holocellulose is composed of cellulose and a complex mixture of polymers formed from simple saccharides known collectively as hemicelluloses. Hemicelluloses are typically characterized by the xylose, mannose, arabinose, and galactose contents. Microfibrils of cellulose constitute the reinforcing rods of the cell wall. Depending on the natural source, glucopyranose units ranging in number from 305 to 15,300 (Fengel and Wegener, 2003) are polymerized to form cellulose chains. This biopolymer imparts tensile strength to the wall to resist turgor pressure and to allow for growth habit. Lignins also impart strength to cell walls, facilitate water transport, and impede the degradation of cell wall polysaccharides, thus acting as a major line of defense against pathogens, insects, and other herbivores. The composition and crosslinking of lignin have significant impacts on the lignin degradability and susceptibility to kraft delignification (Chen et al., 2001; Grabber, 2005). One measure of dicotyledonous angiosperm lignin composition is the content ratio of guaiacyl $(\mathrm{G})$ and syringyl (S) units. These aromatic units determine the type and number of crosslinks. The physical relationship between holocellulose and lignin affects many fiber characteristics. Variation in the chemical content of wood is generally influenced by the interaction of developmental, seasonal, and geographic conditions (Sewell et al., 2002). However, to the best of our knowledge, no studies have evaluated the effects of propagation techniques on cell wall chemistry in woody plants.

One of the key traits that seems to encapsulate, if not link, many of the plant functional traits is tissue density. In particular, for woody plants, the density of woody tissue appears to be central in many aspects of plant form, function, and diversity. Wood density describes the proportion of a stem that is tissue and cell walls (i.e., secondary xylem conduit walls) and the space within cell walls (i.e., secondary xylem conduit apertures) (Swenson and Enquist, 2007). In angiosperm tree species, vessel size (the transverse lumen area of individual vessels) and vessel density (number of vessels per transverse unit area) are the primary indicators of vascular strategy (Zanne and Falster, 2010).
Recently, we have found that G-rich lignin was involved in successful defense of infected elms against DED (Durkovič et al., 2014). The previous study has revealed that the dutch elm hybrid cultivar Dodoens, a popular street tree, showed tolerance to the current prevalent strain of DED, O. novo-ulmi ssp. americana $\times$ novo-ulmi (Ďrkovič et al., 2013). The objectives of this study were: 1) to determine whether routinely applied vegetative propagation techniques that maintain true types of elm genotypes (i.e., in vitro micropropagation vs. widely used grafting of past decades) would affect lignin content and lignin monomer composition in the stems of this dutch elm hybrid; and 2) to identify the differences between micropropagated plants and the grafts with respect to contents of cell wall components, the macromolecular traits of cellulose, neutral sugar composition, plus vessel and fiber anatomy traits, to reveal any mechanical advantages or compensations for either stock type.

\section{Materials and Methods}

Plant Material, Study Site, AND Sampling. The experiments were conducted on clonally micropropagated and grafted plants of the dutch elm hybrid cultivar Dodoens, which has shown tolerance to an aggressive isolate M3 of O. novo-ulmi ssp. americana $\times$ novo-ulmi (Durkovič et al., 2013). The procedure of in vitro micropropagation through axillary and adventitious shoot formation on woody plant and DX culture media supplemented with 6-benzylaminopurine has been described in detail by Krajňáková and Longauer (1996). In this study, the authors also confirmed the genetic identity of micropropagated plants without an occurrence of somaclonal variation. The grafted plants were obtained through splice grafting, which consisted of joining a 'Dodoens' scion onto the stem of a DED-tolerant U. pumila 'Puszta' rootstock to reduce the possibilities of DED transmission by root graft connections in the soil (Green et al., 1985). Grafting of scions onto rootstock was performed $2 \mathrm{~cm}$ upward from the root-stem junction, and the scions used for both grafting and in vitro culture establishment originated from identical donor plants. Three-year-old micropropagated and grafted plantlets of uniform size were selected and then planted in the experimental field plot at Banská Belá, Slovakia (lat. $48^{\circ} 28^{\prime} \mathrm{N}$, long. $18^{\circ} 57^{\prime} \mathrm{E}$, altitude $590 \mathrm{~m}$ ). Proper care was taken during planting to avoid damage to the root system. The planting holes were dug with a spacing of $2 \times 3 \mathrm{~m}$. No post-planting treatments such as irrigation, fertilization, etc., were applied. According to the meteorological station at Arboretum Kysihýbel in Banská Stiavnica (altitude $540 \mathrm{~m}$ ), located $3.6 \mathrm{~km}$ southwest of the study site, the climate of the area is characterized by a mean annual temperature of $7.7^{\circ} \mathrm{C}$ and a mean annual precipitation of $831 \mathrm{~mm}$. The study site soil, which has a silt loam texture, is identified as an Eutric Cambisol formed from the slope deposits of volcanic rocks (andesite and pyroclastic materials).

The sampling was done during the winter season after completion of the tenth growing season after planting. Wood discs $2 \mathrm{~cm}$ thick were sampled $20 \mathrm{~cm}$ above the tree base from the micropropagated plants and $20 \mathrm{~cm}$ above the graft union from the grafts; i.e., $22 \mathrm{~cm}$ above the soil level. The discs were symmetrical, visibly free of reaction wood, and did not contain knotwood. For each examined trait, measurements were performed on five randomly chosen plants per stock type, which were unaffected by DED.

Preparation and determination of extractives. The bark was peeled off the wood samples, and the wood was frozen and 
stored at $-18^{\circ} \mathrm{C}$ before chemical analyses. Separated wood was mechanically disintegrated to sawdust, and a fraction size of 0.5 to $1.0 \mathrm{~mm}$ was extracted in a Soxhlet apparatus with a mixture of ethanol and toluene (2:1) for $8 \mathrm{~h}$ according to the American Society for Testing and Materials (ASTM) International standard procedure D 1107-96.

DETERMINATIONS OF LIGNIN CONTENT AND LIGNIN MONOMER COMPOSITION. Lignin content was determined according to the U.S. Department of Energy, National Renewable Energy Laboratory analytical procedure (Sluiter et al., 2010). The samples were hydrolyzed in a two-stage process. In the first stage, $72 \%(\mathrm{w} / \mathrm{w}) \mathrm{H}_{2} \mathrm{SO}_{4}$ at a temperature of $30{ }^{\circ} \mathrm{C}$ was used for $2 \mathrm{~h}$, and in the second stage, the samples were refluxed after dilution to $4 \%$ (w/w) $\mathrm{H}_{2} \mathrm{SO}_{4}$ for $4 \mathrm{~h}$.

Nitrobenzene oxidation (NBO) was carried out using $2 \mathrm{M}$ $\mathrm{NaOH}$ in $10-\mathrm{mL}$ stainless steel vessels at a temperature of $180{ }^{\circ} \mathrm{C}$ for $2 \mathrm{~h}$ (Ďurkovič et al., 2012). An analysis of oxidation products was performed with a high-performance liquid chromatography (HPLC) system (1200; Agilent Technologies, Santa Clara, CA) equipped with Agilent ChemStation software. The isocratic HPLC was conducted on a $2.6-\mu \mathrm{m}, 100 \times 4.6-\mathrm{mm}$ column (Kinetex C18; Phenomenex, Torrance, CA) coupled with a C18 SecurityGuard cartridge (Phenomenex). The column and detector temperatures were set at $35^{\circ} \mathrm{C}$. The mobile phase consisted of water:methanol:propionic acid (840:160:1), and the flow rate was $1.0 \mathrm{~mL} \cdot \mathrm{min}^{-1}$. The syringyl-to-guaiacyl $(\mathrm{S} / \mathrm{G})$ ratio in lignin was calculated by the following formula: $\mathrm{S} / \mathrm{G}=$ (syringaldehyde + syringic acid)/(vanillin + vanillic acid).

DETERMINATIONS OF CELLULOSE CONTENT AND MACROMOLECULAR TRAITS OF CELlulose. Cellulose content was determined by the Seifert method (Seifert, 1956). A mixture of acetylacetone, dioxane, and hydrochloric acid $(6: 2: 1.5)$ under reflux for $30 \mathrm{~min}$ was used for delignification of wood samples.

Molecular weight distribution analysis of the cellulose samples was performed after their conversion into cellulose tricarbanilates. Cellulose tricarbanilates were dissolved in tetrahydrofuran and filtered through a Puradisc 25 NYL filter (Whatman International, Maidstone, U.K.) with a pore size of $0.45 \mu \mathrm{m}$. Size-exclusion chromatography was performed at $35{ }^{\circ} \mathrm{C}$ with tetrahydrofuran at a flow rate of $1 \mathrm{~mL} \cdot \mathrm{min}^{-1}$ on two PLgel, 10- $\mu \mathrm{m}, 7.5 \times 300-\mathrm{mm}$, MIXED-B columns (Agilent Technologies) preceded by a PLgel, $10-\mu \mathrm{m}, 7.5 \times 50-\mathrm{mm}$, Guard-column (Agilent Technologies) as described by Kačík et al. (2009). Data acquisitions were carried out with ChemStation software (Agilent Technologies) and calculations were performed with the Clarity GPC module (DataApex, Prague, Czech Republic). Numerical outputs were obtained for $M_{\mathrm{n}}$ (number-average molecular weight) and $M_{\mathrm{w}}$ (weight-average molecular weight), and the values were recalculated to underivatized cellulose using a coefficient $\mathrm{k}=162 \mathrm{~g} \cdot \mathrm{mol}^{-1} / 519 \mathrm{~g} \cdot \mathrm{mol}^{-1}$. Polydispersity index (PDI) of cellulose was calculated as the ratio $M_{\mathrm{w}} / M_{\mathrm{n}}$. Degree of polymerization $\left(\mathrm{DP}_{\mathrm{w}}\right)$ values were calculated by dividing the molecular weight by the monomer equivalent weight of anhydroglucose $\left(\mathrm{DP}_{\mathrm{w}}=M_{\mathrm{w}} / 162\right)$.

Fourier-transform infrared spectroscopy (FT-IR) spectra of wood powder samples were recorded on an FT-IR spectrometer equipped with a Smart iTR attenuated total reflectance sampling accessory (Nicolet iS10; Thermo Fisher Scientific, Waltham, MA). The spectra were acquired by accumulating 64 interferograms at a resolution of $4 \mathrm{~cm}^{-1}$ in an absorbance mode (A) at wave numbers from 4000 to $400 \mathrm{~cm}^{-1}$. Spectral bands were measured using OMNIC 8.0 software (Thermo
Fisher Scientific). Crystallinity of cellulose indices were calculated for lateral order index [LOI $\left.\left(\mathrm{A}_{1422} / \mathrm{A}_{897}\right)\right]$ according to O'Connor et al. (1958), and for total crystallinity index [TCI $\left(\mathrm{A}_{1371} / \mathrm{A}_{2884}\right)$ ] according to Nelson and O'Connor (1964b).

DETERMINATIONS OF POLYSACCHARIDE CONTENT AND NEUTRAL SUGAR COMPOSITION. Total content of polysaccharides (i.e., holocellulose) was determined using the method of Wise et al. (1946). Qualitative and quantitative analyses of saccharides were carried out by HPLC according to the ASTM International standard procedure E 1758-01. The samples were hydrolyzed in a two-stage process. In the first stage, $72 \%(\mathrm{w} / \mathrm{w})$ $\mathrm{H}_{2} \mathrm{SO}_{4}$ at a temperature of $30^{\circ} \mathrm{C}$ was used for $1 \mathrm{~h}$, and in the second stage, the formed oligomers were hydrolyzed to monosaccharides after dilution to $4 \%(\mathrm{w} / \mathrm{w}) \mathrm{H}_{2} \mathrm{SO}_{4}$ at a temperature of $121^{\circ} \mathrm{C}$ for $1 \mathrm{~h}$. The analyses were performed with a HPLC chromatograph (1200; Agilent Technologies) equipped with an Aminex HPX-87P column (Bio-Rad Laboratories, Hercules, $\mathrm{CA}$ ) at a temperature of $80^{\circ} \mathrm{C}$ and a mobile phase flow rate of $0.6 \mathrm{~mL} \cdot \mathrm{min}^{-1}$.

SCANNING ELECTRON MiCROGRAPHY. Wood samples were immediately immersed in formaldehyde-ethanol-acetic acid fixative solution and stored overnight in a refrigerator at $4{ }^{\circ} \mathrm{C}$. For scanning electron micrography (SEM), wood sections (transverse, radial, and tangential surfaces) were mounted on specimen stubs, sputter-coated with gold, and observed by highvacuum SEM using a Tescan instrument (VEGA TS 5130; Tescan, Brno, Czech Republic) operating at $15 \mathrm{kV}$.

VESSEL AND FIBER TRAITS. Vascular characteristics were determined for the outer three growth rings using the NISElements image analysis software (Laboratory Imaging, Prague, Czech Republic). Vessel lumen areas $(A)$ and vessel densities per square millimeter of wood $(N)$ were determined from each transverse stem section. Measurements of $A$ and calculations of $N$ were made on the population of vessels, which ranged from 217 to 280 vessels per square millimeter of wood. The additional indicators of vascular strategy such as vessel lumen fraction $(F=A \cdot N)$ and the vessel size:number ratio $(S=A / N)$ were also calculated (Zanne et al., 2010). Total theoretical relative conductivity (RC) per square millimeter was calculated as the sum of individual RCs divided by the area of secondary xylem section, whereas the individual RC was calculated according to Zimmermann (1983) as the fourth power of the equivalent circle diameter of vessel lumen.

For the fiber morphology determination, the phloem and cortex were peeled off and the remaining wood was macerated in a boiling solution containing hydrogen peroxide and acetic acid (1:1) according to the procedure described in Chaffey et al. (2002). Fiber length, fiber width, shape factor (ratio between projected length and real fiber length), and the proportion of fiber length classes (less than $0.20 \mathrm{~mm}, 0.20$ to $0.49 \mathrm{~mm}, 0.50$ to $0.99 \mathrm{~mm}, 1$ to $3 \mathrm{~mm}$ ) were determined with a fiber tester $(\mathrm{L} \& \mathrm{~W}$; Lorentzen \& Wettre, Kista, Sweden). Measurements were performed on five replicates per stock type, and the number of fibers within each population of replicate ranged from 20,002 to 20,276 cells.

Statistical analysis. Data showed a normal distribution and were therefore analyzed by Student's $t$ test. In the case of five traits $(\mathrm{S} / \mathrm{G}$ ratio in lignin, both absolute yields and relative proportions of L-arabinose, $F$, and fiber length class 0.50 to $0.99 \mathrm{~mm}$ ), variance differences between the stock types were significant, and therefore a $t$ test for unequal variances was 
used. In the remaining cases, variance differences between the stock types were non-significant, and a $t$ test for equal variances was used.

Multivariate associations among 30 wood traits were analyzed using a principal component analysis (PCA) to describe patterns of covariation among the content of main cell wall components, lignin monomer composition, macromolecular traits of cellulose, neutral sugar composition, vascular characteristics, and fiber traits.

\section{Results and Discussion}

CONTENTS OF CELL WALL COMPONENTS AND LIGNIN MONOMER composition. Non-significant differences between the stock types were found for the contents of cellulose and extractives (Table 1). However, the grafts reached higher contents of both lignin and holocellulose than the micropropagated plants. This difference might perhaps be attributed to the effect of the rootstock. Gonçalves et al. (2006) documented that the concentration of several leaf metabolites such as starch, total phenolics, total chlorophyll, and total carotenoids was significantly influenced by the rootstock genotype in grafted Prunus avium trees. In addition, the effect of the rootstock was also reported for the content of quebrachitol (a cyclic polyol stereoisomer of inositol) in latex samples of grafted mature Hevea brasiliensis trees (do Nascimento et al., 2011). Higher lignin content found in the grafts is usually responsible for higher adhesion among mechanically active wood fibers (Mancera et al., 2012) plus higher strength, hydrophobicity, and rigidity to the secondary cell walls of water-conducting and supportive tissues (Bonawitz and Chapple, 2010). Higher lignin content also enhances energy storage properties of wood under dynamic loads (Mousavioun et al., 2013) and reduces the growth strain and creep behavior of wood (Wang et al., 2010).

Based on the analysis of NBO products (Table 2), the proportion of $\mathrm{S}$ and $\mathrm{G}$ units in lignin was balanced, and there was a non-significant difference in the $S / G$ ratio between the stock types. This indicates that propagation techniques had no direct effect on lignin monomer composition; hence, no advantage could be attributed to either stock type toward an enhanced tolerance to DED. In addition, the representation of $p$-hydroxyphenyl units in both stock types was almost negligible. In angiosperms, lignin macromolecular structure depends on the proportion of $\mathrm{S}$ and $\mathrm{G}$ aromatic units, which determine the type and number of crosslinks within the macromolecule as well as the reactivity of the lignin. Lignin rich in $G$ units has relatively more carbon-carbon bonds than lignin rich in $\mathrm{S}$ units because the aromatic C-5 position of $\mathrm{G}$ units is free to make linkages. Nitrobenzene oxidation products originate from the corresponding phenylpropane units and their $\alpha(\beta)-\mathrm{O}-4$ alkylaryl ethers as a result of the oxidation of lignin in an alkaline environment. Thus, the $\mathrm{S} / \mathrm{G}$ ratio provides information regarding the relative amounts of uncondensed guaiacyl- and syringyl-propane units constituting the original lignin. In addition, the yield of these aldehydes reflects the degree of condensation of the lignin, because these uncondensed structures are cleaved by the nitrobenzene oxidation leaving condensed lignins as the residue (Kačík et al., 2012). Recent studies revealed that the $\mathrm{S} / \mathrm{G}$ ratio has a significant influence on crosslinking between lignin and other cell wall components, thus modifying the microscopic structure and topochemistry of the cell wall. We have found that only G-rich lignin was involved in successful defense of infected elms against $O$. novo-ulmi ssp. americana $\times$ novo-ulmi (Ďurkovič et al., 2014). Lignin rich in $\mathrm{G}$ units (Vane et al., 2006) as well as ferulate and monolignol metabolites (Lloyd et al., 2011) were also found to be major sources of plant resistance against white-rot and necrotrophic fungi, respectively.

MACROMOLECUlAR TRAITS OF CELlulose AND NEUTRAL SUGAR COMPosition. The micropropagated plants reached higher values for the molecular size distribution traits such as $M_{\mathrm{w}}$ and PDI as well as for $\mathrm{DP}_{\mathrm{w}}$ (Table 3). Owing to its high degree of polymerization, cellulose is considered to be primarily responsible for the tensile strength of wood. Therefore, reducing the length of the cellulose molecules $\left(\mathrm{DP}_{\mathrm{w}}\right)$ would cause a reduction in macro-strength properties (Sweet and Winandy, 1999; Vizárová et al., 2012). From a mechanical point of view, a lower content of holocellulose in the micropropagated plants

Table 1. Contents of main cell wall components and extractives present in the wood of the dutch elm hybrid 'Dodoens'.

\begin{tabular}{|c|c|c|c|}
\hline \multirow[b]{2}{*}{ Wood component } & \multicolumn{2}{|c|}{ Stock type } & \multirow[b]{2}{*}{$t$ test $(P)$} \\
\hline & Micropropagated & Grafted & \\
\hline$\overline{\text { Lignin [mean } \pm \text { SD }(\%)]}$ & $22.19 \pm 0.22$ & $23.10 \pm 0.25$ & $5.47(0.0016)$ \\
\hline Holocellulose $[$ mean \pm SD $(\%)]$ & $82.46 \pm 0.41$ & $83.19 \pm 0.28$ & $2.96(0.0251)$ \\
\hline Extractives [mean \pm SD $(\%)]$ & $3.47 \pm 0.11$ & $3.62 \pm 0.13$ & $1.72(0.1371)$ \\
\hline
\end{tabular}

Table 2. Nitrobenzene oxidation (NBO) products present in the wood of the dutch elm hybrid 'Dodoens'.

\begin{tabular}{|c|c|c|c|}
\hline \multirow[b]{2}{*}{ NBO product } & \multicolumn{2}{|c|}{ Stock type } & \multirow[b]{2}{*}{$t$ test $(P)$} \\
\hline & Micropropagated & Grafted & \\
\hline$p$-Hydroxybenzoic acid [mean \pm SD (\%)] & $0.06 \pm 0.00$ & $0.05 \pm 0.01$ & $4.28(0.0052)$ \\
\hline$p$-Hydroxybenzaldehyde [mean \pm SD $(\%)]$ & $0.04 \pm 0.00$ & $0.04 \pm 0.00$ & $2.15(0.0747)$ \\
\hline Vanillin $[$ mean $\pm \mathrm{SD}(\%)]$ & $3.28 \pm 0.19$ & $2.97 \pm 0.12$ & $2.74(0.0338)$ \\
\hline Syringic acid $[$ mean \pm SD $(\%)]$ & $0.52 \pm 0.03$ & $0.42 \pm 0.02$ & $4.90(0.0027)$ \\
\hline Syringaldehyde $[$ mean \pm SD $(\%)]$ & $3.00 \pm 0.13$ & $3.00 \pm 0.05$ & $0.07(0.9427)$ \\
\hline
\end{tabular}

${ }^{\mathrm{z}}$ Syringyl-to-guaiacyl ratio in lignin. 
might be compensated for by a higher value of $\mathrm{DP}_{\mathrm{w}}$ within the cellulose chain to maintain the tensile strength of the wood for this stock type. In addition, no differences were recorded for either crystallinity of cellulose indices. The ratio of IR band areas at 1422 and $897 \mathrm{~cm}^{-1}$ is referred to as LOI, which represents the ordered regions perpendicular to the chain direction. The absorption band at $1422 \mathrm{~cm}^{-1}$ represents $\mathrm{CH}_{2}$ scissoring motion at $\mathrm{C}_{6}$ (Nelson and O'Connor, 1964a, 1964b; Siroký et al., 2010). The $897-\mathrm{cm}^{-1}$ band indicates the vibrational mode involving $\mathrm{C}_{1}$ and the four atoms attached to it, which is characteristic of $\beta$-anomers or $\beta$-linked glucose polymers (Nelson and O'Connor, 1964a, 1964b; Siroký et al., 2010). The ratio of band areas at 1371 and $2884 \mathrm{~cm}^{-1}$ is known as TCI, which represents the overall degree of order in cellulose. The $1371-\mathrm{cm}^{-1}$ band is associated with the bending mode of C-H (Nelson and O'Connor, 1964a, 1964b; Šroký et al., 2010). The 2884- $\mathrm{cm}^{-1}$ band represents $\mathrm{C}-\mathrm{H}$ and $\mathrm{CH}_{2}$ stretching, which is unaffected by changes in crystallinity (Nelson and O'Connor, 1964a; Qiu et al., 2012).

The results for the absolute yields of saccharides and their relative proportions in the wood of the stock types are given in Table 4. Total yields were higher in the micropropagated plants. The most substantial difference between the stock types was found for the relative proportion of D-glucose (Glc), which was significantly higher in the micropropagated plants. The grafts reached higher relative proportions of D-xylose (Xyl), D-mannose (Man), and D-galactose (Gal). Non-significant differences between the stock types were found for the relative proportion of L-arabinose (Ara). do Nascimento et al. (2011) reported different relative amounts of sucrose (a disaccharide composed of Glc and fructose) in latex samples of $H$. brasiliensis trees, which were grafted onto various rootstocks. This clearly indicates the effect of the rootstock on the relative amounts of saccharides in a scion, and it may be a major reason for the differences discovered between the stock types in this study.

Vascular Traits. Both stock types shared ring-porous wood. Wide vessels in earlywood were arranged at the growth ring boundary, whereas narrow vessels in latewood spread in wavy tangential bands (Fig. 1A and D). In wide earlywood vessels, perforation plates were simple, and helical thickenings were absent or rarely present. Vessel walls had alternately arranged intervessel pits, and vessel-ray pits had elongated apertures (Fig. 1B and E). In narrow latewood vessels, perforation plates were simple, and helical thickenings were densely present throughout the body of these vessels. Vessel-ray pits had large circular to elongated apertures (Fig. 1C and F). Wood porosity and vessel anatomy traits (ring-porous wood, simple perforations, alternate intervessel pitting, pits elongate to circular in outline) found in both stock types fully agreed with the diagnostic microscopic characteristics described for the majority of temperate species of the genus Ulmus (Sweitzer, 1971; Wheeler et al., 1989).

Quantitative data for the examined vascular anatomy traits are presented in Table 5. Both stock types performed similarly for traits such as $N, F$, and RC. Significant differences were found for traits $A$ and $S$, when the micropropagated plants

Table 3. Macromolecular traits of underivatized cellulose isolated from the wood of the dutch elm hybrid 'Dodoens'.

\begin{tabular}{|c|c|c|c|}
\hline \multirow[b]{2}{*}{ Trait $^{z}$} & \multicolumn{2}{|c|}{ Stock type } & \multirow[b]{2}{*}{$t$ test $(P)$} \\
\hline & Micropropagated & Grafted & \\
\hline$\overline{M_{\mathrm{n}}(\mathrm{mean} \pm \mathrm{sD})}$ & $19,538 \pm 269$ & $19,357 \pm 308$ & $0.89(0.4091)$ \\
\hline$M_{\mathrm{w}}($ mean $\pm \mathrm{SD})$ & $131,134 \pm 424$ & $126,496 \pm 375$ & $16.39(0.0001)$ \\
\hline $\mathrm{DP}_{\mathrm{w}}($ mean $\pm \mathrm{SD})$ & $810 \pm 3$ & $781 \pm 3$ & $15.80(0.0001)$ \\
\hline LOI $\left(\mathrm{A}_{1422} / \mathrm{A}_{897}\right)($ mean $\pm \mathrm{sD})$ & $1.19 \pm 0.09$ & $1.28 \pm 0.19$ & $0.84(0.4321)$ \\
\hline $\operatorname{TCI}\left(\mathrm{A}_{1371} / \mathrm{A}_{2884}\right)($ mean $\pm \mathrm{SD})$ & $2.40 \pm 0.29$ & $1.63 \pm 0.83$ & $1.76(0.1296)$ \\
\hline
\end{tabular}

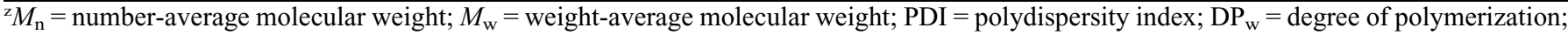
LOI = lateral order index; TCI $=$ total crystallinity index.

Table 4. Absolute yields of saccharides (\% of oven-dry weight per unextracted wood) and their relative proportions (\%) in the wood of the dutch elm hybrid 'Dodoens'.

\begin{tabular}{|c|c|c|c|}
\hline \multirow[b]{2}{*}{ Saccharide $^{z}$} & \multicolumn{2}{|c|}{ Stock type } & \multirow[b]{2}{*}{$t$ test $(P)$} \\
\hline & Micropropagated & Grafted & \\
\hline \multicolumn{4}{|l|}{ Absolute yields } \\
\hline Glc $[$ mean \pm SD $(\%)]$ & $52.99 \pm 0.27$ & $51.96 \pm 0.08$ & $7.10(0.0004)$ \\
\hline $\operatorname{Ara}[$ mean \pm SD $(\%)]$ & $2.25 \pm 0.24$ & $2.08 \pm 0.02$ & $1.34(0.2708)$ \\
\hline $\operatorname{Man}[$ mean $\pm \mathrm{SD}(\%)]$ & $1.76 \pm 0.03$ & $1.93 \pm 0.02$ & $8.72(0.0001)$ \\
\hline \multicolumn{4}{|l|}{ Relative proportions } \\
\hline Glc $[$ mean \pm SD $(\%)]$ & $70.82 \pm 0.21$ & $70.16 \pm 0.21$ & $4.47(0.0042)$ \\
\hline Xyl $[$ mean \pm SD $(\%)]$ & $21.66 \pm 0.20$ & $22.18 \pm 0.19$ & $3.81(0.0089)$ \\
\hline Ara $[$ mean \pm SD $(\%)]$ & $3.01 \pm 0.32$ & $2.81 \pm 0.02$ & $1.20(0.3174)$ \\
\hline $\operatorname{Man}[$ mean $\pm \mathrm{SD}(\%)]$ & $2.34 \pm 0.05$ & $2.60 \pm 0.02$ & $9.44(0.0001)$ \\
\hline Gal $[$ mean \pm SD $(\%)]$ & $2.17 \pm 0.03$ & $2.25 \pm 0.02$ & $5.42(0.0016)$ \\
\hline
\end{tabular}

${ }^{\mathrm{z}}$ Glc $=$ D-glucose, Xyl $=$ D-xylose, Ara $=$ L-arabinose, Man $=$ D-mannose, Gal $=$ D-galactose. 
reached significantly higher values than the grafts. The trait $S$ measures variation in the vessel composition within the water transport space (Zanne et al., 2010). Mean water-conducting area in the micropropagated plants was comprised of a smaller number of larger vessels. A direct impact of higher $A$ and $S$ in the micropropagated plants could be seen in an increased value of $\mathrm{RC}$ for this stock type. In addition, the differences in vascular
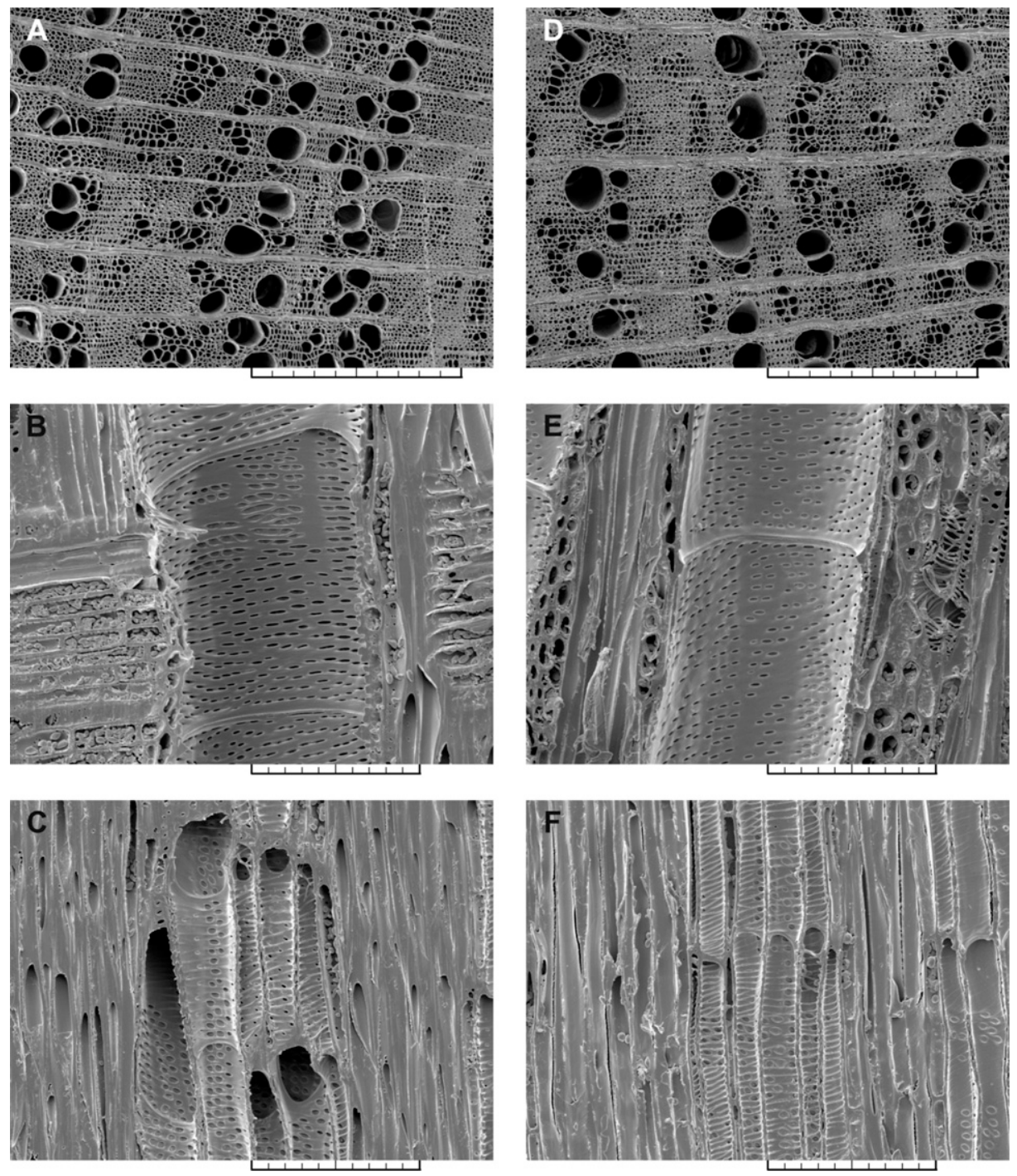

Fig. 1. Scanning electron microscopy images of vascular anatomy in micropropagated (A-C) and grafted (D-F) dutch elm hybrid 'Dodoens'. (A, D) Ring-porous wood in the examined stock types; cross-sections, scale bars = $500 \mu \mathrm{m}$. (B, E) Wide earlywood vessel showing a simple perforation and an alternate pitting arrangement; radial section (B), tangential section $(\mathbf{E})$, scale bars $=100 \mu \mathrm{m} .(\mathbf{C}, \mathbf{F})$ Narrow latewood vessels showing simple perforations and distinct helical thickenings; radial sections, scale bars $=100 \mu \mathrm{m}$. anatomy and hydraulic conductivity among the rootstocks used for grafting can often play a role in the subsequent scion (i.e., stem) vascular growth. Changes in vessel lumen areas over time in the graft union of various $P$. avium heterograft and homograft combinations were reported by Olmstead et al. (2006). The authors found that wound-related callus formation response after grafting led to reduced vessel lumen areas in scion and graft union tissues. Smaller vessels in the graft union of Malus $\times$ domestica 'McIntosh' scions grafted back onto the same rootstocks were also reported by Poniedziałek et al. (1979). In the grafts, these anatomical constraints may be responsible for lower stem hydraulic conductivity, which in turn affects stomatal conductance and net $\mathrm{CO}_{2}$ assimilation rate in leaves (Bayramzadeh et al., 2008; Santiago et al., 2004).

Fiber TRAITs. Libriform fibers showed a similar anatomy in both stock types. The occurrence of simple to slightly bordered slit-like pits clearly seen on radial cell walls (Fig. 2A and B) agreed with the anatomical description of fibers for temperate species of the genus Ulmus provided by Sweitzer (1971). The quantitative data pertinent to fiber length, fiber width, shape factor, and the proportion of fiber length classes are presented in Figure 3. Fiber length was slightly higher in the micropropagated plants, whereas the grafts had slightly wider fibers. It is known that the properties of cellulose chains also determine the properties of wood fibers. In the micropropagated plants, biosynthesis of longer cellulose chains (quantified by a higher value of $\mathrm{DP}_{\mathrm{w}}$ ) resulted in the formation of longer fibers for this stock type. Fiber length and strength have been shown to be particularly important for tearing resistance of wood pulps (Seth and Page, 1988). Fiber width, quantified also by the cell wall thickness, is of particular interest for describing

Table 5. Vascular anatomy traits (per square millimeter of wood) in the dutch elm hybrid 'Dodoens'.

\begin{tabular}{|c|c|c|c|}
\hline \multirow[b]{2}{*}{ Trait $^{z}$} & \multicolumn{2}{|c|}{ Stock type } & \multirow[b]{2}{*}{$t$ test $(P)$} \\
\hline & Micropropagated & Grafted & \\
\hline Vessel lumen area [mean $\left.\pm \mathrm{SD}\left(10^{-4} \mathrm{~mm}^{2}\right)\right]$ & $7.4 \pm 1.1$ & $5.8 \pm 0.5$ & $2.58(0.0418)$ \\
\hline Vessels [mean $\pm \mathrm{SD}\left(\right.$ no. $\left.\left./ \mathrm{mm}^{2}\right)\right]$ & $248 \pm 27$ & $266 \pm 9$ & $1.22(0.2696)$ \\
\hline$S\left[\right.$ mean $\left.\pm \mathrm{SD}\left(10^{-6} \mathrm{~mm}^{4}\right)\right]$ & $3.0 \pm 0.5$ & $2.2 \pm 0.2$ & $2.71(0.0353)$ \\
\hline $\mathrm{RC}\left[\right.$ mean $\left.\pm \mathrm{SD}\left(10^{-4} \mathrm{~mm}^{4}\right)\right]$ & $15.6 \pm 9.0$ & $9.4 \pm 3.6$ & $1.27(0.2505)$ \\
\hline
\end{tabular}

${ }^{\mathrm{z}} F=$ vessel lumen fraction; $S=$ vessel size:number ratio; $\mathrm{RC}=$ relative conductivity. 
fiber quality differences (Paavilainen, 1993) with thick-walled fibers forming bulky sheets of low tensile but high tearing strength (Wardrop, 1969). With regard to shape factor, there were non-significant differences between the stock types. In both stock types, from the four examined fiber length classes, the class of 0.50 to $0.99 \mathrm{~mm}$ was represented by the highest proportion. However, a significantly higher percentage for this class was found in the micropropagated plants. The prevailing proportion for the length class of 0.50 to $0.99 \mathrm{~mm}$ was also reported for libriform fibers of Sorbus aucuparia (Ďurkovič et al., 2011). The grafts had a higher proportion of the classes less than $0.20 \mathrm{~mm}$ and 0.20 to $0.49 \mathrm{~mm}$. There was no difference found between the stock types for the length class of 1 to $3 \mathrm{~mm}$.

Associations among wood traits. PCA was done to evaluate how wood traits were associated (Fig. 4). The first axis explained $49 \%$ of the variation and showed strong positive loadings for $M_{\mathrm{w}}, \mathrm{DP}_{\mathrm{w}}$, and syringic acid. The negative side of the axis indicated strong loadings for the relative proportions of
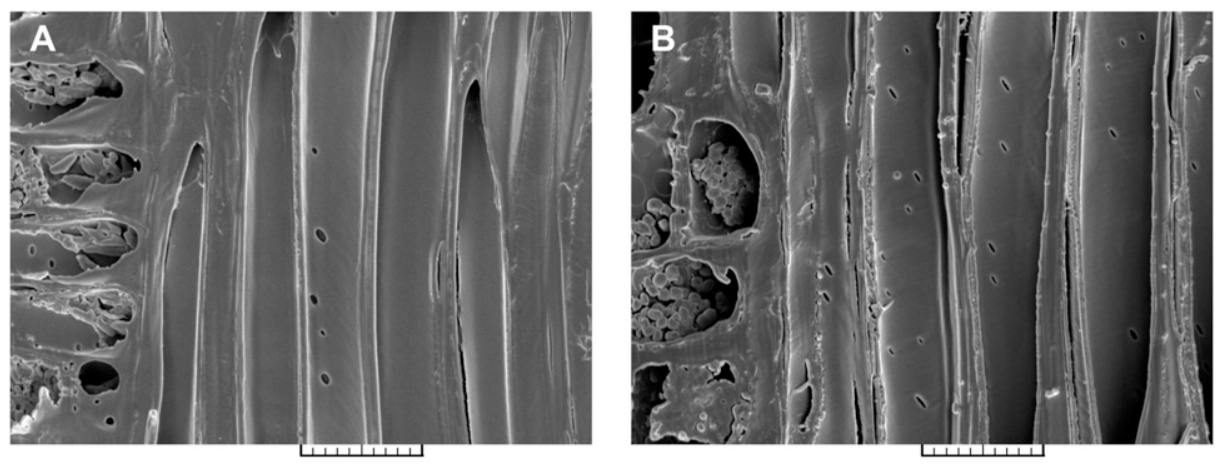

Fig. 2. Scanning electron microscopy images of libriform fibers in micropropagated (A) and grafted (B) dutch elm hybrid 'Dodoens'; radial sections, scale bars $=20 \mu \mathrm{m}$.
Man, Xyl, Gal, and lignin content. The second axis explained $18 \%$ of the variation and showed strong positive loadings for vanillic acid, $F$, and $N$. The negative side of the axis indicated strong loadings for syringaldehyde, the $\mathrm{S} / \mathrm{G}$ ratio in lignin, and $M_{\mathrm{n}}$. The relative proportion of Glc together with the macromolecular traits of cellulose such as $M_{\mathrm{w}}$ and $\mathrm{DP}_{\mathrm{w}}$ were closely associated with both the fiber length and fiber shape factor to ensure the tensile strength for the wood. In addition, both stock types formed compact homogeneous clusters clearly separated from each other in the multivariate wood trait analysis.

\section{Summary}

We found no significant differences in lignin monomer composition and the relative proportion of $\mathrm{G}$ units between micropropagated plants and the grafts. Seen from a phytopathological point of view, no advantage could be attributed to either stock type toward an enhanced tolerance to DED. However, the grafts did reach a higher lignin content, which could provide minor advantages in terms of mechanical and physical properties to the cell walls of this stock type. Taken together, the micropropagated plants reached significantly higher values for 13 traits $(32.5 \%)$, primarily associated with the relative proportion of Glc and the macromolecular traits of cellulose to compensate for a lower content of holocellulose. The grafts reached higher values for 10 traits $(25 \%)$, including the contents of both lignin and holocellulose as well as the relative proportions of $\mathrm{Xyl}$, Man, and Gal. The effect of the
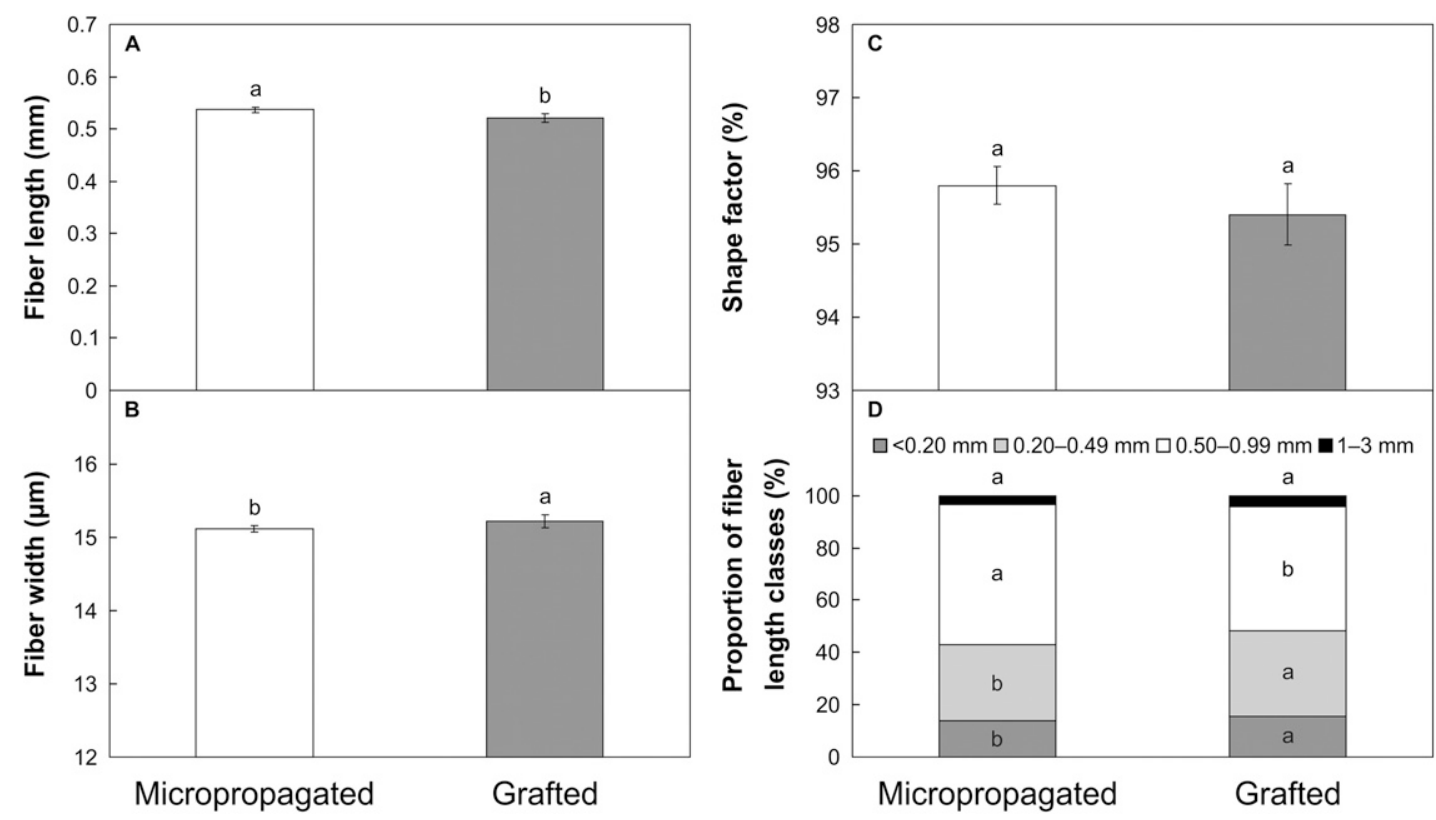

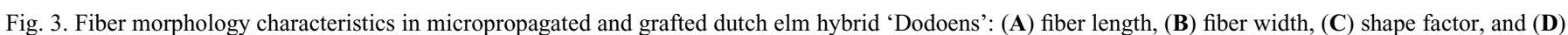
proportion of fiber length classes. Histograms represent means \pm SD. Means followed by the same letter within a particular fiber length class and across stock types are not significantly different at $P<0.05$ ( $t$ test). 


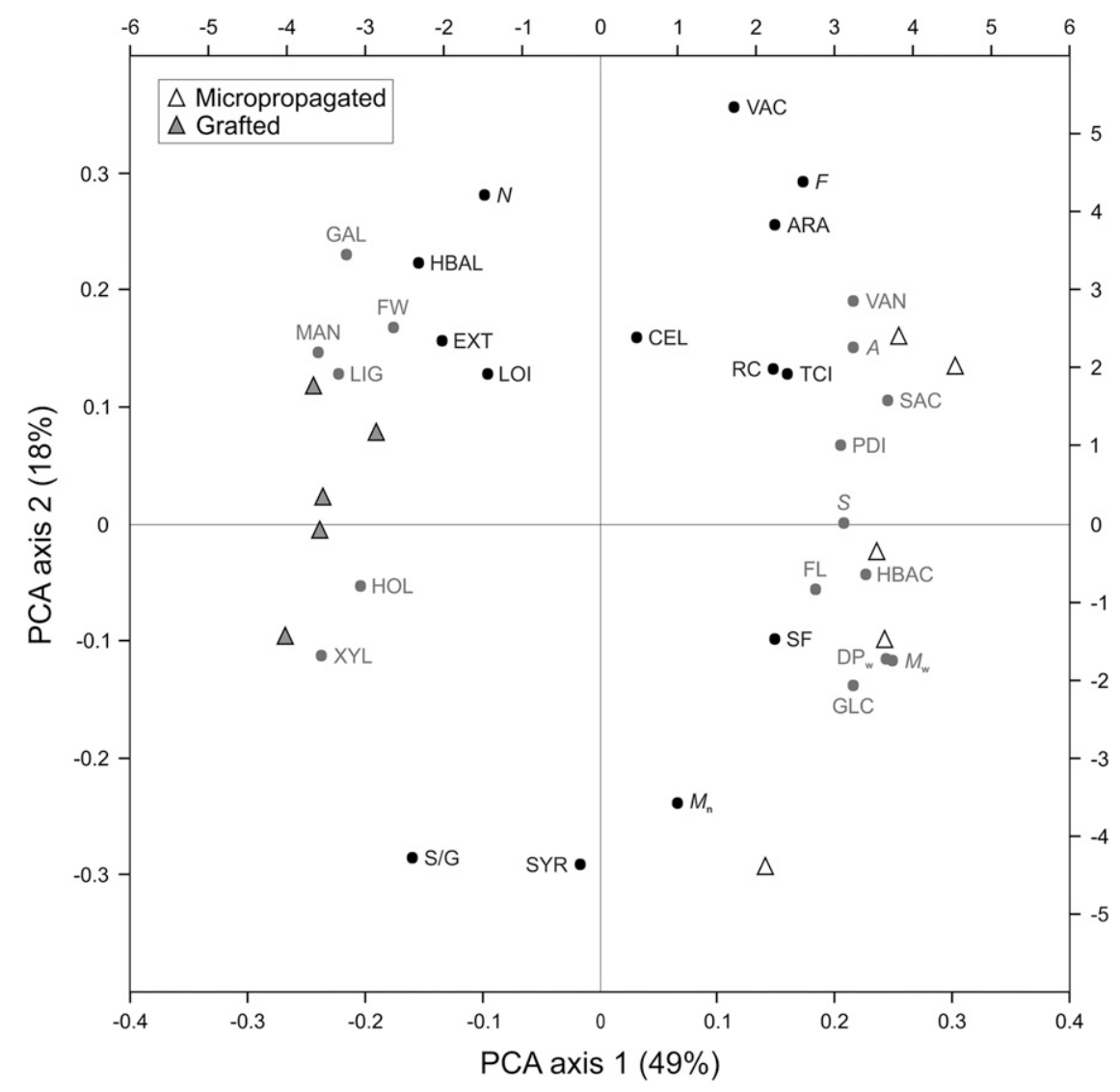

Fig. 4. Positions of 30 wood traits on the first and second axes of the principal component analysis (PCA). Traits associated with significant differences between micropropagated plants and the grafts are indicated in gray: $A=$ vessel lumen area; $\mathrm{ARA}=\mathrm{L}$-arabinose; $\mathrm{CEL}=$ cellulose content; $\mathrm{DP}_{\mathrm{w}}=$ degree of polymerization of cellulose; $\mathrm{EXT}=$ extractives content; $F=$ vessel lumen fraction; $\mathrm{FL}=$ fiber length; $\mathrm{FW}=$ fiber width; GAL $=$ D-galactose; GLC $=$ D-glucose; HBAC $=p$-hydroxybenzoic acid; HBAL $=p$-hydroxybenzaldehyde $; \mathrm{HOL}=$ holocellulose content; $\mathrm{LIG}=$ lignin content; $\mathrm{LOI}=$ lateral order index; $\mathrm{MAN}=\mathrm{D}-$ mannose; $M_{\mathrm{n}}=$ number-average molecular weight; $M_{\mathrm{w}}=$ weight-average molecular weight; $N=$ number of vessels per square millimeter; PDI = polydispersity index; $\mathrm{RC}=$ relative conductivity; $S=$ vessel size:number ratio; $\mathrm{S} / \mathrm{G}=$ syringyl-to-guaiacyl ratio in lignin; $\mathrm{SAC}=$ syringic acid; $\mathrm{SF}=$ shape factor; $\mathrm{SYR}=$ syringaldehyde; $\mathrm{TCI}=$ total crystallinity index; $\mathrm{VAC}=$ vanillic acid; $\mathrm{VAN}=$ vanillin; $\mathrm{XYL}=\mathrm{D}$-xylose. Micropropagated and grafted plants of dutch elm hybrid 'Dodoens' are as indicated in the key.

rootstock might contribute to different amounts of these cell wall substances in the grafts. Similarities between the stock types were found for 17 traits $(42.5 \%)$. Our observations showed that both stock types formed compact homogeneous clusters clearly separated from each other in the multivariate wood trait analysis.

\section{Literature Cited}

Bayramzadeh, V., R. Funada, and T. Kubo. 2008. Relationships between vessel element anatomy and physiological as well as morphological traits of leaves in Fagus crenata seedlings originating from different provenances. Trees (Berl.) 22:217-224.

Biroščíková, M., K. Spišáková, Š. Lipták, V. Pichler, and J. Ďurkovič. 2004. Micropropagation of mature wych elm (Ulmus glabra Huds.). Plant Cell Rep. 22:640-644.

Bonawitz, N.D. and C. Chapple. 2010. The genetics of lignin biosynthesis: Connecting genotype to phenotype. Annu. Rev. Genet. 44:337-363.

Brasier, C.M. 1991. Ophiostoma novo-ulmi sp. nov., causative agent of current dutch elm disease pandemics. Mycopathologia 115:151-161. Brasier, C.M. and S.A. Kirk. 2010. Rapid emergence of hybrids between the two subspecies of Ophiostoma novo-ulmi with a high level of pathogenic fitness. Plant Pathol. 59:186-199.
Chaffey, N., E. Cholewa, S. Regan, and B. Sundberg. 2002. Secondary xylem development in Arabidopsis: A model for wood formation. Physiol. Plant. 114:594-600.

Chen, C., M. Baucher, J.H. Christensen, and W. Boerjan. 2001. Biotechnology in trees: Towards improved paper pulping by lignin engineering. Euphytica 118:185-195.

Conde, P., A. Sousa, A. Costa, and C. Santos. 2008. A protocol for Ulmus minor Mill. micropropagation and acclimatization. Plant Cell Tissue Organ Cult. 92:113-119.

do Nascimento, E.S.P., C.R. de Oliveira, P. de Souza Gonçalves, R.B. da Costa, R.M.B. Moreno, L.H.C. Mattoso, and A.G. Ferreira. 2011. Effect of rootstock on the scion of Hevea brasiliensis through metabolic analysis of latex samples by ${ }^{1} \mathrm{H}$ NMR. Crop Breeding Appl. Biotechnol. 11S1:82-88.

Ďurkovič, J., I. Čaňová, R. Lagaňa, V. Kučerová, M. Moravčík, T. Priwitzer, J. Urban, M. Dvořák, and J. Krajňáková. 2013. Leaf trait dissimilarities between dutch elm hybrids with a contrasting tolerance to dutch elm disease. Ann. Bot. (Lond.) 111:215-227.

Ďurkovič, J., I. Čaňová, T. Priwitzer, M. Biroščíková, P. Kapral̆, and M. Saniga. 2010. Field assessment of photosynthetic characteristics in micropropagated and grafted wych elm (Ulmus glabra Huds.) trees. Plant Cell Tissue Organ Cult. 101:221-228.

Ďurkovič, J., F. Kačík, D. Olčák, V. Kučerová, and J. Krajňáková. 2014. Host responses and metabolic profiles of wood components in dutch elm hybrids with a contrasting tolerance to dutch elm disease. Ann. Bot. (Lond.) 114:47-59.

Ďurkovič, J., A. Kaňuchová, F. Kačík, R. Solár, and A. Lengyelová. 2012. Genotype- and age-dependent patterns of lignin and cellulose in regenerants derived from 80 -year-old trees of black mulberry (Morus nigra L.). Plant Cell Tissue Organ Cult. 108:359-370.

Durkovič, J., M. Kardošová, F. Kačík, and M. Masaryková. 2011. Wood traits in parental and hybrid species of Sorbus. Botany 89:559-572.

Fengel, D. and G. Wegener. 2003. Wood: Chemistry, ultrastructure, reactions. Verlag Kessel, Munich, Germany.

Gartland, K.M.A., A.T. McHugh, R.M. Crow, A. Garg, and J.S. Gartland. 2005. Biotechnological progress in dealing with dutch elm disease. In Vitro Cell. Dev. Biol. Plant 41:364-367.

Gerhold, H.D. 1970. A decade of progress in breeding disease-resistant forest trees. Unasylva 24:37-44.

Gonçalves, B., J. Moutinho-Pereira, A. Santos, A.P. Silva, E. Bacelar, C. Correia, and E. Rosa. 2006. Scion-rootstock interaction affects the physiology and fruit quality of sweet cherry. Tree Physiol. 26:93-104. Grabber, J.H. 2005. How do lignin composition, structure, and crosslinking affect degradability? A review of cell wall model studies. Crop Sci. 45:820-831.

Green, C.E., R.P. Guries, and E.B. Smalley. 1985. Early screening of elms for resistance to Ceratocystis ulmi. Plant Dis. 69:60-63.

Harvengt, L., A. Meier-Dinkel, E. Dumas, and E. Collin. 2004. Establishment of a cryopreserved gene bank of European elms. Can. J. For. Res. 34:43-55. 
Heybroek, H.M. 1983. Resistant elms for Europe, p. 108-113. In: Burdekin, D.A. (ed.). Research on dutch elm disease in Europe. Her Majesty's Stationery Office, London, UK.

Hiemstra, J.A., J. Buiteveld, J. Kopinga, K.G. Kranenborg, M.B.M. Ravesloot, B.J. van der Sluis, and S.M.G. de Vries. 2006. Belang en toekomst van de iep in Nederland. Praktijkonderzoek Plant \& Omgeving, Wageningen, The Netherlands.

Kačík, F., J. Durkovič, and D. Kačíková. 2012. Chemical profiles of wood components of poplar clones for their energy utilization. Energies 5:5243-5256.

Kačík, F., D. Kačíková, M. Jablonský, and S. Katuščák. 2009. Cellulose degradation in newsprint paper ageing. Polym. Degrad. Stabil. 94:1509-1514.

Krajňáková, J. and R. Longauer. 1996. Culture initiation, multiplication and identification of in vitro regenerants of resistant hybrid elms. Lesnictví-Forestry 42:261-270.

Lloyd, A., J.W. Allwood, C.L. Winder, W.B. Dunn, J.K. Heald, S.M. Cristescu, A. Sivakumaran, F.J.M. Harren, J. Mulema, K. Denby, R. Goodacre, A.R. Smith, and L.A.J. Mur. 2011. Metabolomic approaches reveal that cell wall modifications play a major role in ethylene-mediated resistance against Botrytis cinerea. Plant J. 67:852868.

Mancera, C., N.-E. El Mansouri, M.A. Pelach, F. Francesc, and J. Salvadó. 2012. Feasibility of incorporating treated lignins in fiberboards made from agricultural waste. Waste Mgt. 32:1962-1967.

Merkle, S.A., G.M. Andrade, C.J. Nairn, W.A. Powell, and C.A. Maynard. 2007. Restoration of threatened species: A noble cause for transgenic trees. Tree Genet. Genomes 3:111-118.

Mousavioun, P., P.J. Halley, and W.O.S. Doherty. 2013. Thermophysical properties and rheology of PHB/lignin blends. Ind. Crops Prod. 50:270-275.

Nelson, M.L. and R.T. O'Connor. 1964a. Relation of certain infrared bands to cellulose crystallinity and crystal lattice type. Part I. Spectra of lattice types I, II, III and of amorphous cellulose. J. Appl. Polym. Sci. 8:1311-1324.

Nelson, M.L. and R.T. O’Connor. 1964b. Relation of certain infrared bands to cellulose crystallinity and crystal lattice type. Part II. A new infrared ratio for estimation of crystallinity in celluloses I and II. J. Appl. Polym. Sci. 8:1325-1341.

Newhouse, A.E., F. Schrodt, H. Liang, C.A. Maynard, and W.A. Powell. 2007. Transgenic American elm shows reduced dutch elm disease symptoms and normal mycorrhizal colonization. Plant Cell Rep. 26:977-987.

O'Connor, R.T., E.F. DuPré, and D. Mitcham. 1958. Applications of infrared absorption spectroscopy to investigations of cotton and modified cottons: Part I: Physical and crystalline modifications and oxidation. Text. Res. J. 28:382-392.

Olmstead, M.A., N.S. Lang, F.W. Ewers, and S.A. Owens. 2006. Xylem vessel anatomy of sweet cherries grafted onto dwarfing and nondwarfing rootstocks. J. Amer. Soc. Hort. Sci. 131:577-585.

Paavilainen, L. 1993. Importance of cross-dimensional fiber properties and coarseness for the characterization of softwood sulphate pulp. Paperi ja Puu 75:35-43.

Poniedziałek, W., W. Lech, and M. Urbanek. 1979. Anatomical changes in the grafted apple bark rings. Fruit Sci. Rpt. 6:115-133.

Qiu, Z., G.M. Aita, and M.S. Walker. 2012. Effect of ionic liquid pretreatment on the chemical composition, structure and enzymatic hydrolysis of energy cane bagasse. Bioresour. Technol. 117:251-256. Santiago, L.S., G. Goldstein, F.C. Meinzer, J.B. Fisher, K. Machado, D. Woodruff, and T. Jones. 2004. Leaf photosynthetic traits scale with hydraulic conductivity and wood density in Panamanian forest canopy trees. Oecologia 140:543-550.

Santini, A., N. La Porta, L. Ghelardini, and L. Mittempergher. 2008. Breeding against dutch elm disease adapted to the Mediterranean climate. Euphytica 163:45-56.
Santini, A., F. Pecori, A.L. Pepori, F. Ferrini, and L. Ghelardini. 2010. Genotype $\times$ environment interaction and growth stability of several elm clones resistant to dutch elm disease. For. Ecol. Mgt. 260:10171025.

Seifert, V.K. 1956. Über ein neues Verfahren zur Schnellbestimmung der Rein-Cellulose. Papier 10:301-306.

Seth, R.S. and D.H. Page. 1988. Fibre properties and tearing resistance. Tappi J. 71:103-110.

Sewell, M.M., M.F. Davis, G.A. Tuskan, N.C. Wheeler, C.C. Elam, D.L. Bassoni, and D.B. Neale. 2002. Identification of QTLs influencing wood property traits in loblolly pine (Pinus taeda L.). II. Chemical wood properties. Theor. Appl. Genet. 104:214-222.

Shukla, M.R., A.M. Jones, J.A. Sullivan, C. Liu, S. Gosling, and P.K. Saxena. 2012. In vitro conservation of American elm (Ulmus americana): Potential role of auxin metabolism in sustained plant proliferation. Can. J. For. Res. 42:686-697.

Široký, J., R.S. Blackburn, T. Bechtold, J. Taylor, and P. White. 2010. Attenuated total reflectance Fourier-transform infrared spectroscopy analysis of crystallinity changes in lyocell following continuous treatment with sodium hydroxide. Cellulose 17:103-115.

Sluiter, A., B. Hames, R. Ruiz, C. Scarlata, J. Sluiter, D. Templeton, and D. Crocker. 2010. Determination of structural carbohydrates and lignin in biomass. Tech. Rpt. NREL/TP-510-42618. National Renewable Energy Laboratory, Golden, CO.

Smalley, E.B. and R.P. Guries. 1993. Breeding elms for resistance to dutch elm disease. Annu. Rev. Phytopathol. 31:325-352.

Sweet, M.S. and J.E. Winandy. 1999. Influence of degree of polymerization of cellulose and hemicellulose on strength loss in fireretardant-treated southern pine. Holzforschung 53:311-317.

Sweitzer, E.M. 1971. Comparative anatomy of Ulmaceae. J. Arnold Arbor. 52:523-585.

Swenson, N.G. and B.J. Enquist. 2007. Ecological and evolutionary determinants of a key plant functional trait: Wood density and its community-wide variation across latitude and elevation. Amer. J. Bot. 94:451-459.

Vane, C.H., T.C. Drage, and C.E. Snape. 2006. Bark decay by the white-rot fungus Lentitula edodes: Polysaccharide loss, lignin resistance and the unmasking of suberin. Int. Biodeterior. Biodegradation 57:14-23.

Vizárová, K., S. Kirschnerová, F. Kačík, A. Briškárová, Š. Šutý, and S. Katušćák. 2012. Relationship between the decrease of degree of polymerisation of cellulose and the loss of groundwood pulp paper mechanical properties during accelerated ageing. Chem. Papers 12:1124-1129.

Wang, Y., J. Gril, B. Clair, K. Minato, and J. Sugiyama. 2010. Wood properties and chemical composition of the eccentric growth branch of Viburnum odoratissimum var. awabuki. Trees (Berl.) 24:541-549. Wardrop, A.B. 1969. Fiber morphology and papermaking. Tappi J. 52:396-404.

Wheeler, E.A., C.A. LaPasha, and R.B. Miller. 1989. Wood anatomy of elm (Ulmus) and hackberry (Celtis) species native to the United States. IAWA Bul. New Ser. 10:5-26.

Wise, L.E., M. Murphy, and A.A. D’Addieco. 1946. Chlorite holocellulose, its fractionation and bearing on summative wood analysis and on studies on the hemicelluloses. Paper Trade J. 122:35-43.

Zanne, A.E. and D.S. Falster. 2010. Plant functional traits-linkages among stem anatomy, plant performance and life history. New Phytol. 185:348-351.

Zanne, A.E., M. Westoby, D.S. Falster, D.D. Ackerly, S.R. Loarie, S.E.J. Arnold, and D.A. Coomes. 2010. Angiosperm wood structure: Global patterns in vessel anatomy and their relation to wood density and potential conductivity. Amer. J. Bot. 97:207-215.

Zimmermann, M.H. 1983. Xylem structure and the ascent of sap. Springer-Verlag, Berlin, Germany. 